УДК 355.45

\author{
С.П. Лещенко, О. М. Колеснік, С.В. Денісенко, М.В. Пилипенко \\ Харківський національний університет Повітряних Сил ім. І. Кожедуба, Харків
}

\title{
ОБГРУНТУВАННЯ ПОКАЗНИКІВ ЯКОСТІ ВИРІШЕННЯ ЗАВДАНЬ ДЛЯ ПОРІВНЯЛЬНОЇ ОЦІНКИ ЕФЕКТИВНОСТІ ПІДРОЗДІЛІВ РАДІОТЕХНІЧНИХ ВІЙСЬК
}

\begin{abstract}
В статті, на основі аналізу наукових пращь та досвіду локальних військових конфліктів, обрані показники та критерій ефективності вирішення завдань системою розвідки повітряного противника, яку створюють радіотехнічні війська, як функціонал від узагальнених показників якості виконання поставлених завдань. Запропоновані узагальнені показники простороих бойових можливостей угруповання підрозділів радіотехнічних військ, а саме, коефіцієнти реалізації потрібних рубежів видачі бойової інформації підрозділам ЗРВ та винищувальної авіації. В якості комплексного показника просторових бойових можливостей угруповання ППО, який забезпечує порівняльну очінку ефективності варіантів побудови бойового порядку угруповання РТВ, запропоновано використовувати коефіцієнт прикриття об'єкту. Нормоване значення комплексного показника - коефіцієнту прикриття об'єкту залежить від значень узагальнених просторових показників бойових можливостей угруповання підрозділів РТВ та у вигляді логічної суми коефіцієнтів прикриття об'єкту підрозділами ЗРВ та ВА дозволяє очінити результат взаємодіі ЗРВ та ВА, при виконанні загальної задачі з прикриття визначеного важливого об'єкту. Використання наведених узагальнених просторових показників бойових можливостей підрозділів РТВ та комплексного показника ефективності угруповання ППО може дати можливість підвищити об'єктивність та інформативність результату порівняльної оиінки варіантів побудови бойового порядку угруповання РТВ. Використання запропонованих показників для порівняльного очінювання ефективності не протирічить існуючим науковим підходам $і$, водночас, дозволяє формалізувати методику вибору позичій для підрозділів угруповання РТВ.
\end{abstract}

Ключові слова: угруповання радіотехнічних військ, критерій ефективності, комплексний показник, вибір позииій, відбиття удару засобів повітряного нападу.

\section{Вступ}

Постановка проблеми. Зміни в тактиці застосування військ (сил), пов'язані з масовим впровадженням в практику застосування військ автоматизованих систем управління військами і зброєю, високоточної зброї, засобів радіоелектронної боротьби та безпілотних авіаційних комплексів різного призначення визначають основні тенденції ведення збройної боротьби у повітряному просторі та, як наслідок, потребують подальшого розвитку форм та способів застосування Повітряних Сил. Ефективне застосування Повітряних Сил Збройних Сил України сьогодні потребує переходу від масованого застосування у визначений час до “адаптованих дій” на основі удосконалених та нових інтегрованих систем розвідки, автоматизованих систем управління військами та озброєнням [1].

Досвід останніх локальних військових конфліктів показує на необхідність удосконалення оперативності та достовірності оперативно-тактичних розрахунків та необхідності використання імітаційного моделювання бойового застосування підрозді- лів під час планування для перевірки запропонованих рішень, які потребують сучасні умови застосування підрозділів Повітряних Сил та радіотехнічних військ, які у свою чергу створюють нову інтегровану систему розвідки повітряного противника (СРПП), з використанням автоматизованих систем збору та обробки інформації про повітряну обстановку та додаткових джерел інформації про польоти цивільної авіації [2].

Як показує досвід проведення операції Об'єднаних Сил, основними складнощами при плануванні застосування міжвидових мобільних вогневих підрозділів, які потребують подальших досліджень, $є$ [3]: обгрунтування раціонального складу підрозділу протиповітряної оборони; вибір бойового порядку, який забезпечує ефективне застосування створеного угруповання ППО; порядок організації управління, взаємодії, логістичного забезпечення та радіолокаційного забезпечення, що вимагає розгляду питання вибору раціонального бойового порядку угруповання підрозділів РТВ, які виконують завдання $з$ радіолокаційного забезпечення міжвидового угруповання ППО. 
Вже сьогодні в країнах НАТО практично реалізована прийнята 32010 року концепція побудови розподілених мереж імітації та моделювання, яка визначає порядок управління моделюванням, розподіл об'єктів та структур, які залучаються для формування розподілених мереж імітаційного моделювання, максимально наближаючи при цьому бойову обстановку, яка моделюється, до реальної по просторово-часовому розмаху та кількості сил і засобів, що залучаються. Інститут інженерів з електроніки та електротехніки (IEEE) розробив і затвердив серію стандартів IEEE 1516, що описують принципи високорівневої архітектури розподілених мереж імітаційного моделювання. Завдяки такій стандартизації з'явилася можливість організувати складні віртуальні навчання, в яких беруть участь модельні засоби військових відомств країн НАТО [4-5]. Такий систематизований підхід до використання розподілених мереж імітації та моделювання підтверджує, що діяльність командирів та штабів при виробленні рішення на бойове застосування об'єктивно сполучається із застосуванням методів кількісного аналізу, математичного прогнозування ефективності прийнятих рішень, які розробляються.

Вибір та обгрунтування адекватних узагальнених показників та критерію ефективності угруповання підрозділів радіотехнічних військ для проведення розрахунків бойових можливостей та моделювання бойового застосування підрозділів РТВ у складі міжвидового угруповання військ, дає можливість підвищити об'єктивність та інформативність результату порівняльної оцінки варіантів побудови бойового порядку за рахунок врахування впливу додаткових факторів під час використання інформаційно-розрахункових систем та імітаційного моделювання.

Аналіз останніх досліджень і публікацій. Проблема оцінки ефективності угруповання підрозділів РТВ для проведення порівняльного аналізу та оцінки вкладу в ефективність угруповання ППО досліджувалась у численних публікаціях [5-7]. Автори розділяють чотири підходу до оцінки ефективності системи розвідки повітряного противника: по вартості збережених системою ППО об'єктів, по значенню вкладу до ефективності старшої системи ППО, по сукупності показників якості та одному функціональному узагальненому показнику якості виконання поставленого завдання при обмеженні інших показників.

При першому підході більше оцінюється вартість збережених об'єктів, при другому оцінка суттєво залежить від показників бойових можливостей вогневих засобів системи ППО. Третій підхід вимагає використання експертних оцінок для побудови функціоналу від сукупності окремих узагальнених показників (коефіцієнту проводки цілей, коефіцієн- ту хибних трас, середньоквадратичних похибок, кількості трас, які видаються користувачам та математичного очікування кількості цілей, які видаються користувачам 3 заданою якістю). Іноді фунціонал представляють у вигляді згортки імовірності виконання окремих задач $з$ показниками радіолокаційного забезпечення (імовірності виявлення, зав'язки, супроводження трас, впізнавання та інше).

У більшості робіт, які відповідають третьому підходу, пропонується використовувати узагальнені показники, які слабо пов'язані з кінцевим результатом дій угруповання ППО або використовують складні для проведення практичних розрахунків імовірнісні показники (імовірність видачі радіолокаційної інформації про трасу цілі з заданою якістю, імовірність радіолокаційного забезпечення траси цілі, прибуток імовірності збереження об'єкту прикриття) [6-7]. Причому більшість публікацій до основних показників ефективності бойових дій угруповань ППО, як старшої системи яку забезпечує СРПП, відносять узагальнені функціональні показники, які мають зрозумілий фізичний сенс, але які характеризують ефективність системи ППО в цілому (математичне очікування (МОЧ) кількості знищених цілей, імовірність ураження заданої кількості цілей до досягнення ними рубежу виконання завдань) [7-8].

Однак оперувати однією кількісною оцінкою збережених об'єктів або математичним очікування кількості знищених цілей, яка у більшості залежить від вогневих можливостей засобів зенітнихракетних військ (ЗРВ) та винищувальної авіації (ВА) і слабо корелює з результатами бойового застосування підрозділів РТВ недостатньо. Оцінка ефективності бойового застосування угруповання підрозділів РТВ, як результату сумісних дій ЗРВ, винищувальної авіації та системи розвідки повітряного противника повинна враховувати просторовий характер дій та враховувати особливості виконання завдань 3 радіолокаційного забезпечення ЗРВ та ВА угрупованням підрозділів РТВ у складі системи ППО. Виходячи із вище зазначеного, можна свідчити про недосконалість існуючого науково-методичного апарату оцінки ефективності системи розвідки повітряного противника, який потребує покращення у оперативності та достовірності оцінок, врахування просторово-розподіленого характеру застосування угруповання підрозділів РТВ та формування необхідного переліку узагальнених показників бойових можливостей та критерію для проведення порівняльного аналізу ефективності угруповання підрозділів РТВ і реалізації методики вибору раціонального варіанту побудови бойового порядку угруповання підрозділів РТВ.

Розглянемо існуючі показники бойових можливостей радіотехнічних частин і підрозділів, які 
можливо розраховувати на етапах проведення оперативно-тактичних розрахунків та імітаційного моделювання. Також розглянемо послідовність вибору варіанту побудови бойового порядку угруповання підрозділів РТВ та оцінки очікуваної ефективності його бойового застосування.

Метою статті $\epsilon$ визначення напрямків удосконалення існуючих підходів до оцінки ефективності системи розвідки повітряного противника, вибір узагальнених показників якості вирішення завдань та критерію для порівняльної оцінки ефективності угруповання підрозділів РТВ, визначення зв'язку цих показників з комплексними показниками ефективності системи протиповітряної оборони об'єктів.

\section{Виклад основного матеріалу}

Під ефективністю угруповання підрозділів РТВ, які складають СРПП будемо розуміти ступінь реалізації бойових можливостей підрозділів щодо видачі радіолокаційної інформації з заданою якістю для радіолокаційного забезпечення користувачів інформації [3-5]. Для оцінки ефективності потрібно сформувати перелік узагальнених показників бойових можливостей, обрати комплексний показник та критерій, які повинні відображати результативність функціонування СРПП під час виконання покладених завдань $з$ радіолокаційного забезпечення. Узагальнені показники бойових можливостей повинні враховувати основні показники $з$ повноти, точності та достовірності радіолокаційної інформації та характеризувати просторові параметри СРПП, які найбільш залежать від варіантів побудови (розміщення на місцевості) угруповання підрозділів РТВ [3; 6; 9]. Обраний перелік узагальнених показників та критерій ефективності повинні забезпечувати оцінку якості виконання покладених на СРПП завдань та мати чіткий фізичний смисл і бути пов'язаними з комплексними показниками ефективності системи ППО об'єктів.

При побудові моделей бойових дій використовують наступні методи моделювання: імітаційні (статистичні), аналітичні, стохастичні, комбіновані та штучного інтелекту. При цьому математичні моделі повинні відповідати основним вимогам щодо достовірності результатів, оперативності отримання результатів, системності та модульності при побудові моделі, відповідності ступеня деталізації рівню моделювання, вхідній інформації, точності і формі представлення даних [9]. В практиці радіотехнічних військ найбільше поширення отримали математичні моделі побудовані за графоаналітичними та аналітичними методиками розрахунків показників бойових можливостей (наприклад, інформаційно-розрахункова система (IPC) “Віраж-РД”) [9-10]. В основу графоаналітичної методики розрахунку просторових бойових можливостей частин i підрозділів РТВ покладається розрахунок параметрів зон виявлення окремих радіолокаційних засобів 3 урахуванням затінюючих властивостей рельєфу місцевості та поєднання окремих зон виявлення у радіолокаційне поле. Також в IPC розраховуються потрібні та реалізовані рубежі видачі розвідувальної та бойової інформації за відомими аналітичними виразами [8; 11-12].

Оцінка якості виконання СРПП поставленого завдання щодо забезпечення ведення бойових дій ЗРВ та ВА може здійснюватися шляхом розрахунку узагальненого показнику просторових бойових можливостей, в якості якого оберемо коефіцієнт реалізації просторових бойових можливостей $-K_{p n p} . \mathrm{У}$ загальному вигляді коефіцієнт $K_{p n p}$ може бути представлений як відношення об'єму $V_{p л n ~}$ частини повітряного простору в якій реалізована видача споживачеві РЛІ заданої якості, до необхідного об'$\epsilon$ му $V_{\text {рлптр }}$ повітряного простору, в якому необхідно отримувати інформацію радіолокації про повітряні цілі із заданою якістю [6]. На практиці, даний показник може бути замінений на більш відомий показник просторових бойових можливостей - коефіцієнт реалізації потрібного рубежу видачі радіолокаційної інформації $K_{p n p}$, що розраховується як відношення дальності видачі радіолокаційної інформації, що реалізується $Д_{p j}$, на заданій висоті в јому напрямку до потрібної дальності видачі радіолокаційної інформації $Д_{m p j}$ [11-12]:

$$
K_{p n p}=\frac{1}{N} \cdot \sum_{j=1}^{N} K_{p n p j}, \partial e\left\{\begin{array}{l}
\kappa_{p n p_{j}}=\frac{Д_{p}}{Д_{m p j}}, n p u Д_{p} \leq Д_{n p} \\
\kappa_{p n p_{j}}=1, n p u Д_{p} \succ Д_{m p}
\end{array},(1)\right.
$$

де $N$ - кількість напрямків, на яких здійснюється оцінка.

Усереднена за всі напрямки оцінка коефіцієнта $K_{\text {pnp }}$ може бути використана в якості узагальненого показника оцінки якості радіолокаційного забезпечення бойовою та розвідувальною інформацією бойових дій ЗРВ або винищувальної авіації для обраної висоти польоту цілі при вирішенні завдання прикриття заданого об'єкту в межах операційної зони.

Відповідно комплексний показник якості радіолокаційного забезпечення ведення бойових дій ЗРВ та винищувальної авіації має просторовий характер, та оцінюється у вигляді простороворозподіленої функції комплексного показника $Q_{\text {pnpi }}$ :

$$
Q_{\text {pnpi }}=f\left(B(i), L(i), H(i), K_{\text {pnpi }}\right),
$$

де $B(i), L(i), H(i)$ - просторові координати повіт- 
ряного простору, для яких оцінюється кількість, типаж РЕТ (підрозділів РТВ) системи розвідки повітряного противника, які задіяні для обслуговування цієї $i$-ї точки повітряного простору та значення комплексного показника ефективності системи розвідки повітряного противника при виконанні поставлених тактичних завдань щодо забезпечення ведення бойових дій ЗРВ та авіації - $Q_{p n p i}$. Оцінювання значення комплексного показника ефективності системи розвідки повітряного противника при виконанні поставлених тактичних завдань $Q_{p n p i}$ пропонується здійснювати за допомогою методів оцінцки якості об’єктів. Відомо, що при оцінці поведінки складної системи діє правило супераддітивного нелінійного складання, відповідно до якого функція ефективності не дорівнює сумі функцій ефективності складових iii частин. В [6] отримано вираз для функціоналу узагальненого показника якості виконання окремих тактичних задач, який може бути представлено у вигляді виразу для нормованого комплексного показника ефективності системи розвідки повітряного противника при виконанні поставлених тактичних завдань щодо забезпечення ведення бойових дій ЗРВ та авіації:

$$
Q_{p n p i}=\frac{-\log _{2}\left[1-\prod_{j=1}^{m}\left(1-2^{-K p n p_{j i}^{r j}}\right)\right]}{-\log _{2}\left[1-\left(\frac{1}{2}\right)^{m}\right]},
$$

де $K_{\text {pnpji }}$ - значення $j$-го узагальненого нормованого показника $K_{p n p i}$ якості радіолокаційного забезпечення підрозділів ЗРВ або ВА для $i$-ї точки повітряного простору;

$r_{j}$ - ступінь важливості (ваги) $j$-го узагальненого нормованого показника. Ваги можуть обиратися експертами.

Цей комплексний показник є нормованою безрозмірною величиною. Максимальне значення $Q_{\text {pnрi }}$ при цьому дорівнює одиниці. Значення нормованого комплексного показника ефективності СРПП при виконанні поставлених тактичних завдань щодо радіолокаційного забезпечення підрозділів ЗРВ та авіації може використовуватися як критерій для порівняння варіантів побудови бойового порядку угруповання підрозділів РТВ. Такий критерій має ясний сенс і характеризує результат оцінки якості радіолокаційного забезпечення підрозділів ЗРВ та радіолокаційного забезпечення винищувальної авіації для $i$-ої точки повітряного простору.

Таким чином, значення простороворозподіленого комплексного показника $Q_{p n p i}$ буде залежати від значень узагальнених просторових показників якості радіолокаційного забезпечення: ко- ефіцієнту реалізації потрібного рубежу видачі радіолокаційної інформації для максимальної реалізації бойових можливостей ЗРВ $-K_{\text {рпрзрв }}$ та коефіцієнту реалізації потрібного рубежу видачі радіолокаційної інформації винищувальної авіації - $K_{\text {рпрва }}$.

Вагові коефіцієнти, які входять до виразу (3) визначаються методом експертних оцінок з обробкою результатів експертних оцінок одним з відомих методів [6].

Кількісна оцінка узагальнених показників бойових можливостей при цьому не залежить від випадкових подій, які трапляються в процесі протиповітряного бою, таких як флуктуації ефективної поверхні розсіяння цілі при руху по трасі, зміни потужності та просторового положення джерел перешкод, вплив на радіоелектронну техніку (РЕТ) авіаційних засобів ураження та інше.

При проведенні оперативно-тактичних розрахунків, за рахунок обмеження деталізації, отримують потрібну оперативність розрахунків просторових показників бойових можливостей РТВ. Але результати таких розрахунків не враховують динаміку та характер дій повітряного противника, що є суттєвим недоліком, який можливо виправити лише при використанні методу імітаційного моделювання, який дозволяє для варіантів дій ЗПН оцінити інтегральні показники ефективності угруповання ППО (коефіцієнт проводки повітряних цілей, математичне очікування кількості знищених цілей, кількість стрільб по трасах повітряних цілей). Порядок проведення оперативно-тактичних розрахунків, оцінки ефективності та визначення раціонального варіанту побудови бойового порядку може бути зведений до таких етапів [3; 6]:

- визначення базових варіантів побудови бойового порядку. На цьому етапі за результатами оцінки обстановки (оцінки противника, своїх військ) на підставі проведення розрахунків параметрів радіолокаційного поля, зон вогню підрозділів ППО, визначається необхідний склад та декілька варіантів оперативного шикування угруповання підрозділів РТВ для виконання задач з радіолокаційного забезпечення користувачів в операційній зоні;

- виключення малоефективних варіантів побудови бойового порядку на підставі оцінки їх ефективності за результатами проведення оперативнотактичних розрахунків узагальнених просторових показників бойових можливостей з радіолокаційного забезпечення користувачів інформації (радіолокаційного забезпечення підрозділів ЗРВ та винищувальної авіації) - $K_{\text {рпрзрв }}$ і $K_{\text {рпрзва }}$ та комплексного показника $Q_{p n p i}$. На цьому етапі обираються $2 \ldots 3$ найбільш раціональних варіанта побудови бойового порядку угруповання з урахуванням очікуваної яко- 
сті виконання поставлених завдань для яких значення комплексного показника $Q_{\text {pпрі }}$ приймає максимальне значення;

- оцінка ефективності попередньо обраних варіантів побудови бойового порядку шляхом імітаційного або аналітико-стохастичного моделювання у ситуації, яка найбільш близька до реальних умов функціонування системи розвідки повітряного противника, яку створює угруповання РТВ та системи ППО в цілому [5-7].

Ефективність бойового застосування угруповання РТВ на третьому етапі імітаційного моделювання може оцінюватися по математично очікуваній кількості повітряних цілей, інформацію про які угрупованням РТВ з заданою якістю зможе видавати на пункти управління сил і засобів ППО для забезпечення ведення бойових дій під час нальоту засобів повітряного нападу [8; 10].

Система розвідки повітряного противника $є$ складовою частиною загальної системи ППО. Відповідно значення комплексного показника ефективності системи розвідки повітряного противника $Q_{p n p i}$ повинне корелювати з комплексним показником якості прикриття об'єктів в загальній системі ППО. В роботах $[8 ; 11-12]$ було запропоновано в якості комплексного показника ефективності виконання завдання угрупованням ЗРВ або винищувальної авіації використовувати нормоване значення коефіцієнту прикриття об'єкту.

Оцінка значення комплексного показника ефективності ППО коефіцієнта прикриття $-K_{n p}$, по-

винна дозволяти оцінити можливості змішаного угруповання ЗРВ та винищувальної авіації по прикриттю визначеного важливого об'єкту в межах операційної зони. До нових питань, які потребують окремого дослідження відноситься оцінка результату взаємодії міжвидового угруповання ППО та винищувальної авіації. У більшості існуючої літератури питання взаємодії розглядаються у контексті створення системи управління та оцінки їі властивостей, таких як стійкість та оперативність [13]. Але кількісна оцінка ефективності взаємодії міжвидового угруповання ППО та винищувальної авіації при виконанні спільного завдання з ППО важливого об'єкту потребує удосконалення та обгрунтування відповідних показників. Розглянемо особливості оцінки комплексного показника прикриття об'єкту $K_{n p}$, який дозволяє оцінити якість виконання завдань 3 прикриття важливого об'єкту угруповання ЗРВ та винищувальної авіації при вирішенні спільного завдання.

Основною задачею ЗРВ та винищувальної авіації щодо прикриття об'єкту є недопущення виходу цілі на рубіж виконання завдання. Розрахунок відповідного коефіцієнту прикриття $K_{n p}$ здійснюється за відомим виразом [11-12]:

$$
\begin{gathered}
K_{n p}(\beta)=\left\{\begin{array}{cc}
1, & \text { якщо } \quad Д_{\text {факт }}(\beta) \geq Д_{\text {потр }}(\beta) ; \\
0, \quad \text { інакше }
\end{array}\right. \\
K_{n p}=\frac{1}{N} \sum_{i=1}^{N} k(\beta),
\end{gathered}
$$

де $Д_{\text {факт }}(\beta)$ - фактичний рубіж знищення цілі при польоті до рубежу виконання завдання на напрямку $\beta$.

$$
Д_{\text {потр }}(\beta) \text { - потрібний рубіж знищення цілі на }
$$
напрямку $\beta$.

Кількість напрямків $\beta$ дорівнює $N$.

Фактично коефіцієнт прикриття об'єкту кількісно дорівнює відсотку напрямків, на яких забезпечується знищення повітряної цілі до досягнення ціллю рубежу виконання бойового завдання для варіанту польоту цілі на об'єкт.

Приклад розрахунку у інформаційно-розрахунковій системі “Віраж-РД” рубежу виконання завдання ЗПН, потрібних та реалізованих рубежів видачі бойової інформації, реалізованого рубежу та МОЧ знищення ЗПН на малих висотах по напрямкам для учбового угруповання підрозділів РТВ та 3РВ, наведений на рис. 1. Розрахунок показує суттєві зміни значення МОЧ кількості цілей в залежності від напрямку польоту повітряних цілей, яке залежить від реалізованих рубежів видачі бойової інформації $K_{\text {рпрзрв }}$ та виносу об'єкту прикриття за межі реалізованої зони вогню підрозділів ЗРВ. Розраховане значення коефіцієнту прикриття об'єкту підрозділом ЗРВ - $K_{\text {прзвв }}$ приймає значення менше одиниці та також залежить від просторових показників бойових можливостей угруповання РТВ, значення яких у свою чергу суттєво залежить від типів та тактико-технічних характеристик засобів радіолокації підрозділів РТВ [14].

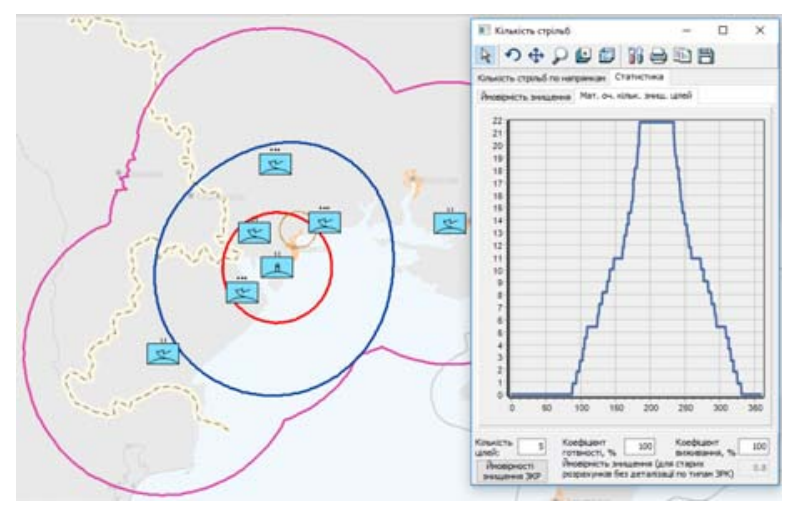

Рис. 1. Приклад розрахунку рубежів видачі БІ, рубежу знищення та МОЧ цілей по напрямках для учбового угруповання підрозділів ЗРВ та РТВ Джерело: розроблено авторами. 
Приклад розрахунку у інформаційнорозрахунковій системі “Віраж-РД” для учбового варіанту чергування на аеродромі винищувальної авіації потрібних та реалізованих рубежів видачі бойової інформації, реалізованого рубежу перехоплення та МОЧ знищених цілей на малих висотах по напрямкам, наведений на рис. 2. Розрахунок показує суттєві зміни значення МОЧ кількості перехоплених цілей в залежності від напрямку польоту та від реалізованих рубежів видачі бойової інформації підрозділами РТВ.

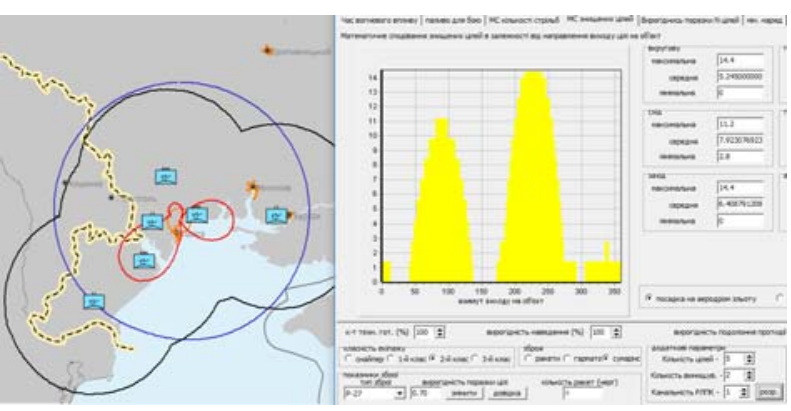

Рис. 2. Приклад розрахунку рубежів видачі БІ, рубежу перехоплення та МОЧ цілей по напрямках для учбового угруповання підрозділів РТВ та ВА Джерело: розроблено авторами.

Розглянемо можливий варіант показника, який дозволяє проводити кількісну оцінку результату взаємодії угруповання ЗРВ та винищувальної авіації при вирішенні спільного завдання 3 прикриття важливого об'єкту у складі міжвидового угруповання ППО. Перевагою такого комплексного показника ефективності виконання завдання угрупованням ППО - коефіцієнту прикриття $K_{\text {прппо }} \epsilon$ можливість оцінювати взаємний вклад ЗРВ та ВА у результуючу ефективність під час оцінці їх взаємодії шляхом логічного поєднання результатів розрахунків коефіцієнтів прикриття об'єкту, які отримані окремо для ЗРВ та винищувальної авіації. Такий підхід дозволяє оцінювати взаємо-доповнення можливостей підрозділів ЗРВ та винищувальної авіації при вирішення спільного завдання 3 прикриття об'єкту (збільшення

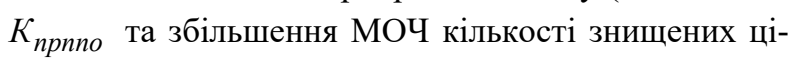
лей під час розподілу зусиль по напрямкам та рубежам):

$$
K_{\text {прппо }}(\beta)=K_{\text {прзрв }}(\beta) \cap K_{\text {прва }}(\beta) .
$$

Приклад розрахунку МОЧ перехоплених цілей для винищувальної авіації під час чергуванні на ае-

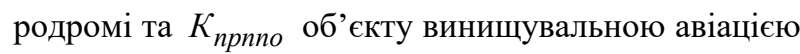
наведені на рис. 3 .

На рис. 4 наведений учбовий варіант розрахунку МОЧ знищених та перехоплених повітряних цілей для варіанту сумісних дій при розподілу зусиль по рубежам та напрямкам підрозділів ЗРВ та авіації.

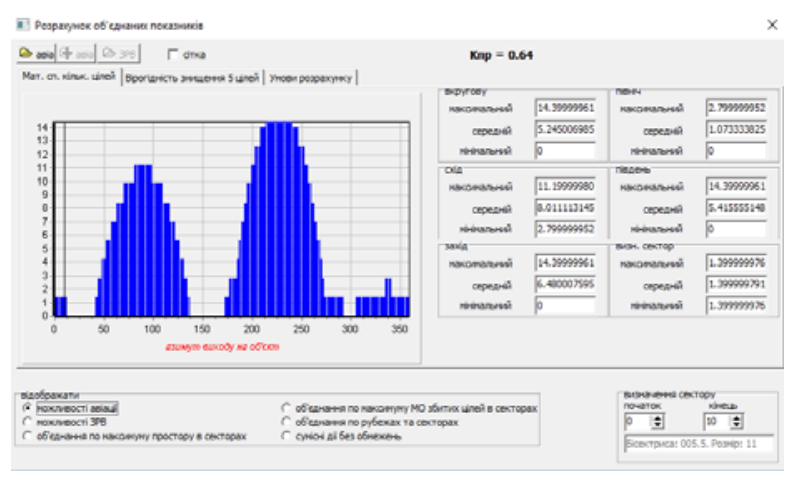

Рис. 3. Приклад розрахунку МОЧ перехоплених цілей та $K_{n р в а}$ по напрямках для ВА

Джерело: розроблено авторами.

Розрахунок показує збільшення значення коефіцієнту прикриття об'єкту $K_{n p n п о ~}$ від 0.64 до 0.86 , що відповідає збільшенню відсотків напрямків, на яких забезпечується перехоплення (знищення) повітряних цілей для варіанту сумісних дій авіації та ЗPB.

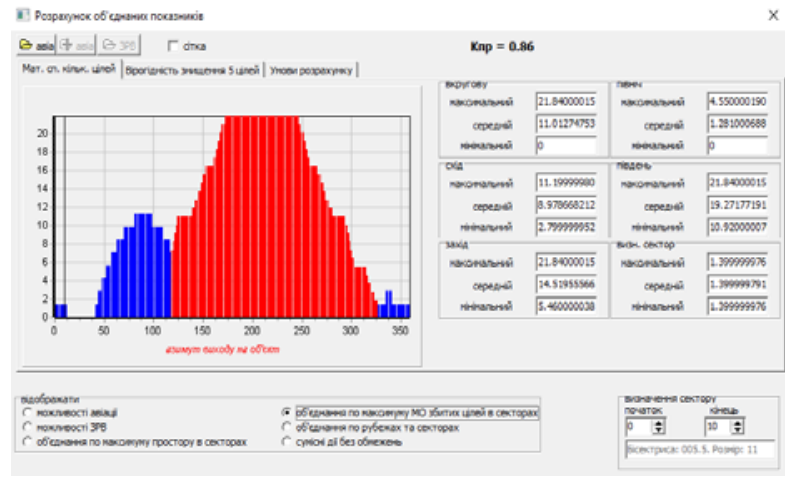

Рис. 4. Приклад розрахунку МОЧ знищених повітряних цілей для ЗРВ і ВА та $K_{\text {nрппо }}$

для сумісних дій по напрямкам

Джерело: розроблено авторами.

Таким чином комплексний показник ефективності виконання завдання угрупованням ППО -

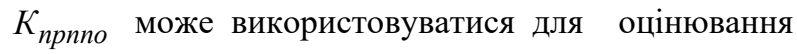
взаємного вкладу ЗРВ та ВА у результуючу ефективність угруповання ППО під час оцінки їх взаємодії.

\section{Висновки}

В статті, на основі аналізу наукових праць та досвіду останніх локальних збройних конфліктів обрані показники і критерій оцінювання ефективності системи розвідки повітряного противника та комплексні показники ефективності системи ППО в цілому, які забезпечують підвищення об'єктивності та інформативності їі оцінки, а саме:

- узагальнені просторові показники якості радіолокаційного забезпечення: коефіцієнт реалізації потрібного рубежу видачі радіолокаційної інформа- 
ції для максимальної реалізації бойових можливостей ЗРВ - $K_{\text {рпрзрв }}$ та коефіцієнт реалізації потрібного рубежу видачі радіолокаційної інформації винищувальної авіації $-K_{\text {рпрва }}$;

- просторово-розподілений комплексний показник $Q_{\text {pпрі }}$ ефективності СРПП при виконанні поставлених тактичних завдань щодо радіолокаційного забезпечення підрозділів ЗРВ та авіації, який запропоновано використовуватися як критерій ефективності системи розвідки повітряного противника для порівняння варіантів побудови бойового порядку угруповання підрозділів РТВ;

- комплексний показник ефективності виконання завдання угрупованням ППО у складі підрозділів РТВ, ЗРВ та винищувальної авіації у вигляді коефіцієнту прикриття об'єкту $-K_{\text {прппо }}$.

\begin{abstract}
Запропонований комплексний показник $K_{\text {прппо }}$ ефективності виконання завдання угрупо-
\end{abstract} ванням ППО, який може використовуватися для оцінювання взаємного вкладу ЗРВ та ВА у результуючу ефективність угруповання ППО під час оцінки їх взаємодії по рубежам та напрямкам при вирішенні спільного завдання 3 прикриття важливого об'єкту. Наведені показники враховують можливості різних засобів ППО та способи їх дій, вплив на результуючу ефективність системи ППО просторових показників бойових можливостей угруповання підрозділів РТВ. У статті наведений порядок проведення етапів оперативно-тактичних розрахунків, імітаційного моделювання та визначення раціонального варіанту побудови бойового порядку угруповання РТВ з використанням запропонованих узагальнених та комплексних показників.

\section{Список літератури}

1. Шамко В.С. Розвиток форм і способів застосування Повітряних Сил Збройних Сил України в сучасних умовах ведення збройної боротьби / В.С. Шамко, О.М. Жарик, В.В. Коваль // Наука і техніка Повітряних Сил Збройних Сил України. - 2018. - № 2(31). - С. 9-15. https://doi.org/10.30748/nitps.2018.31.01.

2. Використання інформації ADS-B в інтересах підвищення якості ведення радіолокаційної розвідки повітряного простору / С.П. Лещенко, О.М. Колесник, С.А. Грицаєнко, С.І. Бурковський // Наука і техніка Повітряних Сил Збройних Сил України. - 2017. - № 3(28). - С. 69-75. https://doi.org/10.30748/nitps.2017.28.09.

3. Ярош С.П. Обгрунтування організації зенітного ракетно-артилерійського прикриття угруповань військ з застосуванням міжвидових мобільних вогневих підрозділів ППО / С.П. Ярош, Б.М. Рябуха, Р.А. Соломонович // Наука і техніка Повітряних Сил Збройних Сил України. - 2020. - № 2(39). - С. 77-82. https://doi.org/10.30748/nitps.2020.39.09.

4. Ярецький А.М. Впровадження розподілених тренажно-моделюючих систем в процес підготовки та науково технічну діяльність Повітряних Сил Збройних Сил України / А.М. Ярецький // Наука і техніка Повітряних Сил Збройних Сил України. - 2017. - № 2 (27). - С. 36-41. https://doi.org/10.30748/nitps.2017.27.06.

5. Гогонянц С. Ю. Вибір показників оцінювання живучості угрупування радіотехнічних військ / С.Ю. Гогонянц, В.М. Крищенко, О.М. Колеснік // Системи озброєння і військова техніка. - 2018. - № 4(56). - С. 7-12. https://doi.org/10.30748/soivt.2018.56.01.

6. Критерий эффективности системы разведки и контроля воздушного пространства / Г.Г. Камалтынов, А.Н. Колесник, М.В. Бейлин, Д.Ю. Свистунов // Системи обробки інформації. - 2003. - № 1(23). - С. 193-201.

7. Гогонянц С.Ю. Загальні положення удосконаленої методики оцінки ефективності радіолокаційного забезпечення бойових дій угруповання сил і засобів протиповітряної оборони / С.Ю. Гогонянц, С.В. Поліщук // Наука і техніка Повітряних Сил Збройних Сил України. - 2016. - № 4(25). - С. 70-73.

8. Жарик О.М. Методика оцінки прикриття важливих державних об'єктів від терористичних актів 3 використанням літальних апаратів / О.М. Жарик // Збірник наукових праць Харківського університету Повітряних Сил. 2012. - № 3(32). - С. 166-177.

9. Обгрунтування напрямків удосконалення моделі оперативного розрахунку параметрів радіолокаційного поля / О.М. Колеснік, М.В. Бардаков, Л.В. Бейліс, В.М. Крищенко // Наука і техніка Повітряних Сил Збройних Сил України. 2016. - № 1(22). - С. 64-67.

10. Створення, впровадження, досвід використання та перспективи розвитку комплексу оперативно-тактичних розрахунків та імітаційного моделювання “Віраж” / С.П. Лещенко, С.І. Бурковський, М.П. Батуринський, Л.В. Польшина, А.А. Адаменко, І.А. Кулініч, Д.Ю. Свистунов // Збірник наукових праць Харківського національного університету Повітряних Сил. - 2017. - № 5(54). - С. 80-84.

11. Оцінка імовірнісних показників можливостей по прикриттю визначених об'єктів винищувальною авіацією в програмному комплексі моделювання бойових дій “Віраж-РД” / С.П. Лещенко, С.І. Бурковський, О.І. Бобикіна, О.М. Жарик // Збірник наукових праць Харківського університету Повітряних Сил. - 2011. - № 3(29). - С. 19-24.

12. Оцінювання показників бойових можливостей по прикриттю визначених об'єктів угрупуванням зенітних ракетних військ за допомогою програмного комплексу оперативно-тактичних розрахунків і імітаційного моделювання розіграшу бойових дій “Віраж-РД” / С.П. Лещенко, М.П. Батуринський, С.І. Бурковський, Л.В. Польшина, О.М. Жарик // Збірник наукових праць Харківського національного університету Повітряних Сил. - 2012. - № 2(31). - С. 4-10.

13. Волков А.Ф. Критерії оцінювання ефективності організації взаємодії під час ведення протиповітряної оборони військ / А.Ф. Волков, О.А. Яненко, С.А. Кравченко // Збірник наукових праць Харківського національного університету Повітряних Сил. - 2019. - № 3(61). - С. 7-11. https://doi.org/10.30748/zhups.2019.61.01. 
14. Камалтинов Г.Г. Тенденції розвитку радіолокаційних засобів контролю повітряного простору / Г.Г. Камалтинов, О.М. Колеснік // Збірник наукових праць Харківського національного університету Повітряних Сил. - 2020. № 2(64). - C. 89-95. https://doi.org/10.30748/zhups.2020.64.13.

\section{Відомості про авторів:}

\section{Лещенко Сергій Петрович}

доктор технічних наук професор провідний науковий співробітник

Харківського національного університету

Повітряних Сил ім. І. Кожедуба,

Харків, Україна

https://orcid.org/0000-0002-3006-2822

\section{Колеснік Олександр Миколайович}

кандидат технічних наук

старший науковий співробітник

начальник кафедри

Харківського національного університету

Повітряних Сил ім. І. Кожедуба,

Харків, Україна

https://orcid.org/0000-0002-8213-017X

\section{Денисенко Сергій Володимирович}

викладач

Харківського національного університету

Повітряних Сил ім. І. Кожедуба,

Харків, Україна

https://orcid.org/0000-0003-1940-5609

\section{Пилипенко Микола Валентинович} курсант

Харківського національного університету

Повітряних Сил ім. І. Кожедуба,

Харків, Україна

https://orcid.org/0000-0002-7892-687X

\section{Information about the authors:}

\author{
Serhii Leshchenko \\ Doctor of Technical Sciences Professor \\ Lead Research \\ of Ivan Kozhedub Kharkiv National \\ Air Force University, \\ Kharkiv, Ukraine \\ https://orcid.org/0000-0002-3006-2822
}

\author{
Oleksandr Kolesnik \\ Candidate of Technical Sciences \\ Senior Research \\ Head of Department \\ of Ivan Kozhedub Kharkiv National \\ Air Force University, \\ Kharkiv, Ukraine \\ https://orcid.org/0000-0002-8213-017X
}

\section{Serhii Denisenko}

Instructor

of Ivan Kozhedub Kharkiv National

Air Force University,

Kharkiv, Ukraine

https://orcid.org/0000-0003-1940-5609

\author{
Mykola Pylypenko \\ Cadet \\ of Ivan Kozhedub Kharkiv National \\ Air Force University, \\ Kharkiv, Ukraine \\ https://orcid.org/0000-0002-7892-687X
}

\title{
ОБОСНОВАНИЕ ПОКАЗАТЕЛЕЙ КАЧЕСТВА РЕШЕНИЯ ЗАДАЧ ДЛЯ СРАВНИТЕЛЬНОЙ ОЦЕНКИ ЭФФЕКТИВНОСТИ ПОДРАЗДЕЛЕНИЙ РАДИОТЕХНИЧЕСКИХ ВОЙСК
}

\author{
С.П. Лещенко, А.Н. Колесник, С.В. Денисенко, Н.В. Пилипенко
}

В статье, на основе анализа научных трудов и опыта локальных войн и конфликтов, выбраны показатели и критерий эффективности решения задач системой разведки воздушного противника, которую создают радиотехнические войска, как функционал от обобщенных показателей качества решения поставленных задач. Предложены обобщенные показатели пространственных боевых возможностей группировки подразделений радиотехнических войск, а именно, коэффициент реализации требуемых рубежей выдачи боевой информации подразделениям ЗРВ и истребительной авиации. В качестве комплексного показателя пространственных боевых возможностей группировки ППО, который обеспечивает сравнительную оченку эффективности вариантов построения боевых порядков группировок, предложено использовать коэффициент прикрытия объекта. Нормированное значение комплексного показателя - коэффициента прикрытия объекта зависит от значений обобщенных показателей пространственных боевых возможностей группировки подразделений РТВ. Логическая сума коэффициентов прикрытия объекта подразделениями ЗРВ и ВА позволяет оценить результат взаимодействия ЗРВ и ВА при выполнении общей задачи по прикрытию важного объекта. Использование предложенных обобщенных пространственных показателей боевых возможностей подразделений РТВ и комплексного показателя эффективности группировки ПВО, дает возможность повысить объективность и информативность результата сравнительной оценки вариантов построения боевого порядка группировки РТВ. Использование предложенных показателей для сравнительного очуенивания эффективности не противоречит существующим научным подходам и позволяет формализовать методику выбора позиций для подразделений РТВ.

Ключевые слова: группировка радиотехнических войск, критерий эффективности, комплексный показатель, выбор позиции, отражение удара средств воздушного нападения. 


\section{JUSTIFICATION OF THE QUALITY INDICATORS \\ OF THE SOLUTION OF TASKS FOR A COMPARATIVE EVALUATION OF THE EFFICIENCY OF RADIO TECHNICAL TROOPS}

S. Leshchenko, O. Kolesnik, S. Denisenko, M. Pylypenko

The article, based on the analysis of scientific works and experience of local wars and conflicts, indicators and criteria of the effectiveness of solving problems by the reconnaissance system of an air enemy, which are created by radio-technical troops, are selected, as a functional from the generalized indicators of the quality of solution the assigned tasks. Generalized indicators of the spatial combat capabilities of the grouping of radio engineering troops are proposed, namely, the coefficient of implementation of the required boundaries for issuing combat information for AAMT and fighter aircraft troops. As a complex indicator of spatial combat capabilities of the grouping air defence, which provides a comparative evaluation efficiency of options for building combat orders of groupings, suggested to use the cover factor of the object. The normalized value of the complex indicator the coefficient of coverage of the object depends on the values of the generalized indicators of the spatial combat capabilities of the grouping of radio engineering troops. The logical sum of the coefficients of coverage of the object by units of anti-aircraft missile forces and fighter aircraft makes it possible to evaluate the result of interaction between anti-aircraft missile forces and fighter aircraft when performing a common task of covering an important object. The use of the proposed generalized spatial indicators of the combat capabilities of radio engineering troops and a complex indicator of the effectiveness of an air defense grouping makes it possible to increase the objectivity and information content of the result of a comparative assessment of options for building a combat formation of a group of radio engineering forces. The use of the proposed indicators for the comparative assessment of effectiveness does not contradict existing scientific approaches and allows to formalize the methodology for selecting positions for units of radio technical troops.

Keywords: grouping of radio-technical forces, efficiency criterion, complex indicator, position selection, repelling an air attack. 